\title{
MENINGKATKAN HASIL BELAJAR MEMBACA PEMAHAMAN SISWA PADA PELAJARAN BAHASA INDONESIA DI KELAS VII-1 MELALUI METODE MEMBACA SEARCH, QUESTION, READ, RECITE, RECORD AND REVIEW (SQ4R) DI SMP NEGERI 1 PANCUR BATU TAHUN PELAJARAN 2019/2020
}

\author{
Alemina \\ Guru SMP Negeri 1 Pancur Batu \\ sembiring1703@gmail.com
}

\begin{abstract}
Tujuan penelitian ini adalah untuk: (1). Meningkatkan hasil belajar membaca pemahaman siswa, (2). Meningkatkan aktivitas belajar siswa. (3). Meningkatkan pemahaman siswa dan pembelajaran yang menggunakan metode membaca Search, question,read, recite, record and review. Metode yang digunakan dalam penelitian adalah Metode Penelitian Tindakan Kelas dengan menggunakan 2 siklus. Subjek penelitian ini adalah siswa VII-1 SMP Negeri 1 Pancur Batu sebanyak 28 siswa. Instrumen yang digunakan untuk memperoleh data adalah menggunakan test, angket dan observasi. Teknik analisa data yang digunakan adalah dengan metode penilaian yaitu: data yang diperoleh dilakukan evaluasi berdasarkan hasil belajar membaca pemahaman siswa. Evaluasi hasil belajar membaca pemahaman siswa diberi rentang nilai dari 0 - 100. Kemudian data dihitung dari nilai rata-rata siswa, persentase jumlah siswa yang tuntas dan persentase jumlah siswa yang belum tuntas memenuhi kriteria ketuntasan minimal. Hasil Penelitian ini menunjukkan terdapat peningkatan hasil belajar membaca pemahaman dengan menerapkan metode membaca Search, question,read, recite, record and review dengan hasil sebagai berikut: (1) terdapat peningkatan rata-rata hasil belajar membaca pemahaman siswa, dimana pada tes awal rata-rata hasil belajar membaca pemahaman siswa adalah 45,31, pada siklus I meningkatkan menjadi 64,68\% kemudian pada siklus II meningkat lagi menjadi 68,44\%, terdapat peningkatan jumlah siswa yang tuntas, dimana pada tes awal jumlah siswa yang tuntas hanya 0\%, meningkat menjadi 56,25\% pada siklus I kemudian meningkat lagi menjadi $85,71 \%$ pada siklus II, terdapat penurunan jumlah siswa yang tidak tuntas, dimana pada tes awal jumlah siswa yang tidak tuntas mencapai 100\%, pada siklus I menjadi 43,75\% kemudian pada siklus II menurun lagi menjadi 14,29\% dengan kata lain hanya 4 siswa saja yang memperoleh nilai 60 dan selebihnya (24) siswa memperoleh nilai 70 dan di atas 70. Penerapan metode membaca search, question,read, recite, record and review dapat meningkatkan hasil belajar membaca pemahaman siswa.
\end{abstract}

Kata kunci : hasil belajar, membaca pemahaman, metode membaca

\begin{abstract}
The aims of this study are: (1) to improve of student achievement on Reading comprehension at class VII-1 through the serch, question, read, recite, record, review method. (2) to improve learnimg activity of students. And (3) to improve students understanding and learning on serch, question, read, recite, record, review method. The method of this study is classroom action research by using two cycles. The subject of this study is the students of VII-1 grade SMP Negeri 1 Pancur Batu. There are 32 students. The techniques to collecting data are test, questioner and observation. The range score for test is 1-100. The technique of analysing data is to to count the average of percentage of the students who pass the standard minimal score and yet. The resullt of the study are: (1) There are the increasing average of students achivement, where pre-test is 45,31, at first cycle is increasing to 64,68\% and the second cycle is increasing to $68,44 \%$,. There are the increasing of the amount of students who pass the test,
\end{abstract}


at the pre-test the students who pass the test is $0 \%$, and the first cycle it tobe $56,25 \%$ and the second cycle is to be $85,71 \%$. There are the decreasing of the students who fail the test. At pretest there $100 \%$ students are fail and at first cycle is decreasing to be 43,75\% and at second cycle is tobe 14,29\%. On the other hand There are only 4 students who get the score under 70 and 24 students get score more than 70.

Keywords : students achievement, reading comprehension

\section{PENDAHULUAN}

\subsection{Latar Belakang Masalah}

Guru Bahasa Indonesia harus mampu meningkatkan kemampuan siswa dalam membaca, menulis , mendengar dan berbicara. Karena dalam pembelajaran bahsa Inggris, keempat kompetensi inilah yang menjadi tujuan untuk ditingkatkan kompetensinya. Kemampuan guru dalam menerapkan metode membaca adalah salah satu indikator dari kompetensi professional guru. Namun kenyataan dilapangan, guru kelas VII-1 SMP Negeri 1 Pancur Batu Mata Pelajaran Bahasa Indonesia, belum mampu menerapkan metode membaca yang aktif, efektif, inovatif, dan menyenangkan yang dapat meningkatkan minat belajar siswa dalam membbaca pemahaman sehingga hasil belajar membaca pemahaman siswa menjadi rendah. Guru masih menerapkan metode membaca yang konvensional sehingga membuat siswa kurang aktif, agak bosan dan pembelajaran cenderung monoton.

Berdasarkan angket awal tentang minat siswa di dalam mengikuti proses pembelajaran di kelas yang di sebar kepada 28 siswa siswa kelas VII-1 SMP Negeri 1 Pancur Batu, diperoleh fakta sebagai berikut: (1) hanya enam orang siswa yang menyatakan sangat tertarik mengikuti proses pembelajaran, (2) dua puluh lima orang siswa menyatakan kurang tertarik mengikuti proses pembelajaran dan (3) tujuh belas siswa menyatakan tidak tertarik mengikuti pelajaran Bahasa Indonesia.
Sementara itu berdasarkan observasi awal yang dilakukan terhadap siswa di kelas VII-1 ditemukan masalah rendahnya hasil belajar membaca pemahaman siswa untuk mata pelajaran Bahasa Indonesia

Berdasarkan hasil angket minat belajar dan observasi awal tentang siswa di atas, maka dilakukan usaha untuk meningkatkan minat siswa dan hasil belajar membaca pemahaman siswa melalui cara merubah metode membaca yang diterapkan di dalam kelas yang selama ini menggunakan metode membaca konvensional menjadi metode membaca yang berpusat pada siswa. Oleh sebab itu dibuat penelitian yang berjudul "Meningkatkan Hasil belajar membaca pemahaman Siswa Pada Pelajaran Bahasa Indonesia di kelas VII-1 melalui Metode membaca Search, question,read, recite, record and review (SQ4R) di SMP Negeri 1 Pancur Batu Tahun Pelajaran 2019/2020”.

\subsection{Perumusan Masalah}

Berdasarkan identifikasi masalah di atas, maka masalah yang dapat dirumuskan sebagai berikut:

Apakah metode membaca Search, question, read, recite, record and review (SQ4R) dapat meningkatkan hasil belajar membaca pemahaman siswa pada pelajaran Bahasa Indonesia di kelas VII-1 SMP Negeri 1 Pancur Batu Tahun Pelajaran 2019/2020?. 


\subsection{Tujuan Penelitian}

Berdasarkan rumusan masalah di atas, maka dapat ditentukan tujuan dalam penelitian ini, yakni:

Untuk meningkatkan hasil belajar membaca pemahaman siswa pada Pelajaran Bahasa Indonesia di kelas VII-1 SMP Negeri 1 Pancur Batu melalui Metode membaca Search, question,read, recite, record and review (SQ4R) Tahun Pelajaran 2019/2020.

\subsection{Manfaat Penelitian}

Manfaat penelitian ini diharapkan berguna bagi siswa dan guru. Adapun bagi siswa penelitian ini diharapkan:

1. Keaktifan siswa dalam proses pembelajaran meningkat

2. Siswa berani mengemukakan pendapat dengan baik di depan kelas

3. Hasil belajar membaca pemahaman Bahasa Indonesia semakin meningkat.

Sementara itu bagi guru diharapkan:

Dapat merubah pola mengajar guru dari Metode membaca Konvensional menjadi Metode membaca Search, question,read, recite, record and review (SQ4R)

\section{METODE}

\subsection{Tempat Dan Waktu Penelitian}

Penelitian ini dilaksanakan pada SMP Negeri 1 Pancur Batu Kecamatan Pancur Batu Kabupaten Deli Serdangl Provinsi Sumatera Utara. Adapun waktu penelitian ini dilaksanakan selama 6 bulan, yakni mulai dari bulan Juli 2019 sampai Desember 2019.

\subsection{Subjek Penelitian}

Subjek pada penelitian ini adalah siswa VII-1 semester I (ganjil) Tahun Pelajaran 2019/2020 di SMP
Negeri 1 Pancur Batu dengan jumlah siswa sebanyak 28 siswa.

\subsection{Desain Penelitian}

Desain yang digunakan dalam penelitian ini adalah Desain Penelitian Tindakan Kelas dengan menggunakan 2 siklus, yakni: perencanaan, pelaksanaan, evaluasi dan refleksi.

\subsection{Indikator Kinerja}

Adapun indikator kinerja dalam penelitian ini adalah jika $80 \%$ siswa memperoleh nilai sama dengan 70 atau lebih dan $80 \%$ siswa aktif dalam kegiatan belajar mengajar, maka penelitian sudah jenuh sehingga tak perlu dilanjutkan ke siklus berikutnya.

\section{HASIL DAN PEMBAHASAN}

Berdasarkan data hasil belajar membaca pemahaman siswa, penerapan metode membaca search, question,read, recite, record and review (SQ4R) dapat meningkatkan hasil belajar membaca pemahaman siswa. Hal ini dapat dilihat dari hasil belajar membaca pemahaman siswa pada siklus I dan siklus II berikut:

1. Terdapat peningkatan rata-rata hasil belajar membaca pemahaman siswa, dimana pada tes awal rata-rata hasil belajar membaca pemahaman siswa adalah 45,31\%, pada siklus I meningkatkan menjadi $64,68 \%$ kemudian pada siklus II meningkat lagi menjadi $68,44 \%$.

2. Terdapat peningkatan jumlah siswa yang tuntas, dimana pada tes awal jumlah siswa yang tuntas hanya $0 \%$, meningkat menjadi $56,25 \%$ pada siklus I kemudian meningkat lagi menjadi $85,71 \%$ pada siklus II

3. Terdapat penurunan jumlah siswa yang tidak tuntas, dimana pada tes awal jumlah siswa yang tidak tuntas mencapai $100 \%$, pada siklus I menurun menjadi 43,75\% kemudian 
pada siklus II menurun lagi menjadi $14,29 \%$ dengan kata lain hanya 4 siswa saja yang memperoleh nilai 70 ke bawah dan selebihnya (24) siswa memperoleh nilai 70 dan di atas 70. Hal tersebut di atas dapat dilihat pada diagram di bawah ini:

\section{Diagram 4.4}

Hasil belajar membaca pemahaman, Tes Awal, Siklus I, Siklus II

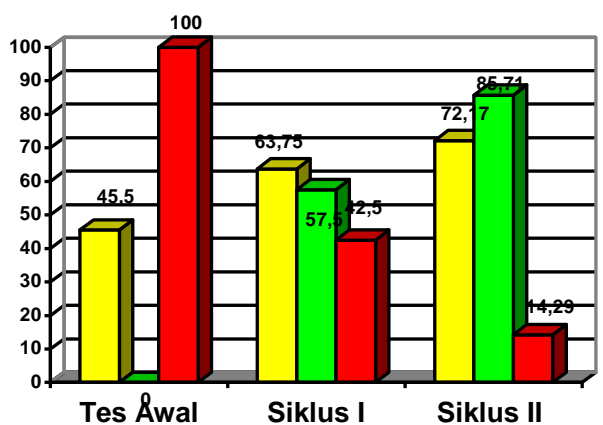

Keterangan:

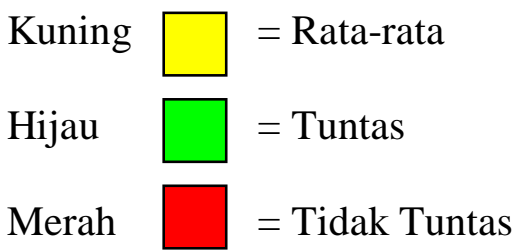

\section{KESIMPULAN}

Berdasarkan hasil belajar membaca pemahaman siswa di atas, maka disimpulkan bahwa: Hasil belajar membaca pemahaman siswa yang diajar menggunakan metode membaca search, question, read, recite, record and review (SQ4R) dapat meningkat, terdapat peningkatan rata-rata hasil belajar membaca pemahaman siswa, dimana pada tes awal rata-rata hasil belajar membaca pemahaman siswa adalah
45,31\%, pada siklus I meningkatkan menjadi $64,68 \%$ kemudian pada siklus II meningkat lagi menjadi $68,44 \%$, terdapat peningkatan jumlah siswa yang tuntas, dimana pada tes awal jumlah siswa yang tuntas hanya $0 \%$, meningkat menjadi $56,25 \%$ pada siklus I kemudian meningkat lagi menjadi $85,71 \%$ pada siklus II, terdapat penurunan jumlah siswa yang tidak tuntas, dimana pada tes awal jumlah siswa yang tidak tuntas mencapai $100 \%$, pada siklus I menjadi $43,75 \%$ kemudian pada siklus II menurun lagi menjadi $14,29 \%$ dengan kata lain hanya 4 siswa saja yang memperoleh nilai 60 dan selebihnya (24) siswa memperoleh nilai 70 dan di atas 70 .

\section{DAFTAR PUSTAKA}

Djamarah, Syaiful Bahri, Zain Aswan, (2010). Metode Belajar Mengajar.Jakarta: Bumi Aksara.

Hamdani. (2011). Metode Belajar Mengajar. Bandung: Pustaka Setia

Mitra Ikhtiar. (2009). Teknik Membaca SQ4R. http// SQ4R

Sanjaya, Wina. (2011). Metode membaca Berorientasi Standar Proses Pendidikan. Jakarta: Kharisma Putra Utama.

Sudjana, Nana. (2010). Penilaian Hasil Proses Belajar Mengajar. (Cet. XV). Bandung: Remaja Rosda Karya.

Sugandi, A. (2004). Teori Pembelajaran. Semarang: UPT MKK Universitas Negeri Malang. 